\title{
Determinants of renewable energy consumption in agrarian Sub-Sahara African economies
}

\author{
Festus Victor Bekun $^{1,2} \cdot$ Andrew Adewale Alola ${ }^{3,4,5}$ \\ ${ }^{1}$ Faculty of Economics Administrative and Social Sciences, Istanbul Gelisim University, Istanbul, Turkey \\ ${ }^{2}$ Department of Economic security, South Ural State University, Chelyabinsk, Russia \\ ${ }^{3}$ Department of Economics, School of Accounting and Finance, University of Vaasa, Vaasa, Finland \\ ${ }^{4}$ Vaasa Energy Business Innovation Centre (VEBIC), University of Vaasa, Vaasa, Finland \\ ${ }^{5}$ Department of Economics and Finance, South Ural State University, Chelyabinsk, Russia
}

Received: 4 November 2020/Revised: 4 February 2022 / Accepted: 4 February 2022/Published online: 2 March 2022

(C) The Author(s) 2022

\begin{abstract}
The effect of ecological distortions and climate change issues have been at the forefront of the minds of policymakers and energy practitioners in recent decades. This concern is associated with the vision of the seventh and thirteenth Sustainable Development Goals that are centered on access to clean energy sources and mitigating climate change issues, as detailed in Vision 2030. To this end, the present study uses Pesaran's Pooled Mean Group Auto Regressive Distributed Lag model to investigate the determinants of clean/non-conventional energy in the case of Sub-Saharan Africa. The empirical results show that a $1 \%$ increase in economic activity increases the level of renewable energy consumption by $0.128 \%$ in the short run. In the long-run, economic growth dampens the consumption of renewable energy by $0.402 \%$ over the investigated period. The reason for this peculiar result for the SubSaharan African economies could be attributed to the prevalent demand for conventional energy sources and the cost-related factor associated with clean energy technologies even when the economy (herein measured by Gross Domestic Product) is improving. Furthermore, the effect of energy (electricity from fossil fuel) also shows a statistically significant impact when trying to reduce the clean energy consumption. This arises from an expected trade-off effect. Regarding the causality analysis using the heterogeneous panel, the causality results present a one-way causality running from economic growth to renewable energy consumption. We also found there to be a feedback causality relationship between urbanization and renewable
\end{abstract}

Andrew Adewale Alola

andrew.alola@uwasa.fi

Festus Victor Bekun

fbekun@gelisim.edu.tr energy as well as agricultural value added and economic growth. Based on these findings, several policy decisions were prescribed for Sub-Saharan African economies such as the diversification of Sub-Saharan African economies energy to more renewable energy sources and the adoption of clean energy technologies that are reputed to be cleaner and environmentally friendly.

Keywords Renewable energy consumption - Agriculture and Sub-Saharan Africa - PMG-ARDL method
Abbreviations
SDGs
EKC Environmental Kuznet curve
EF Ecological footprint
ADF Augmented Dickey-Fuller
VAR Vector autoregressive
ARDL Auto-regressive distributed lag
PMG-ARDL Pesaran's pooled mean group auto regressive distributed
SSA Sub-Saharan African
GHG Global greenhouse gas
OECD Organization for economic corporation and development
GDP Gross domestic product

\section{Introduction}

Notably, renewable energy has continued to retain the spotlight in every climate change debate because solar, wind, hydroelectric, biomass, and thermal power are 
reputable when it comes to energy production without the global warming effect associated with hydrocarbon fuels (National Geographic 2019). In light of the attribution of the climate change concern with the growing environmental damage globally, policy frameworks that are designed for energy portfolio diversification are being adopted by intergovernmental agencies, governments, and other stakeholders. This further affirms the report that there is a $95 \%$ certainty that human activities, especially from the burning of hydrocarbon fuels (conventional energy) such as coal and fossil oil among others, are largely responsible for the global warming issues (National Aeronautics and Space Administration 2020). Considering how climate change is not the only reason that gears the development of renewable energy, there have been consistent debates on the impact of other factors such as the oil and natural gas price, carbon emission certificate vis-à-vis carbon pricing, and financial and economic activities (Aguirre and Ibikunle 2014; Rafiq et al. 2014; Alola and Alola 2018; Ozturk and Dincer 2020; Tugcu et al. 2020; Alola and Saint Akadiri 2021).

In the case of Africa, the continent has portrayed a unique and unusual discussion on both global warming and the energy transition because of its relatively slack progress compared to other continents. Although it is a minor contributor to global greenhouse gas (GHG) emissions and only contributes about $2 \%$ of the aggregate global emissions levels, the continent's GHG emissions is expected to increase to 3\% by 2040 (International Energy Agency 2019). The three major energy sectors of the continent, electricity, heat, and transportation, contribute the largest share of Africa's total GHG emissions. However, the potential of the continent's renewable energy power has been substantially less harnessed compared to the current and projected power consumption of the continent (International Renewable Energy Agency 2019). With the continent reckoned to be the richest solar resources in the world, only about 5 gigawatts $(\mathrm{GW})$ of solar photovoltaic (PV), which is far below $1 \%$ of the global share of solar $\mathrm{PV}$, further signifies the under-utilization of the continent's renewables (International Energy Agency 2019).

However, with the increasing fall in the renewable technology cost across the continent amidst the abundance renewable sources, Africa's solar development is expected to reach about 320 Gigawatts (GWs) in 2040, thus making solar the largest source of electricity in the continent after surpassing hydropower and natural gas (International Energy Agency 2019; Africa Renewable Energy Initiative 2019). The report of the International Energy Agency (2019) has further implied that other sources of renewable energy such as wind in Ethiopia, Kenya, Senegal and South Africa, and geothermal in Kenya are increasingly being developed. The importance of further harnessing renewable energy sources in Africa as indicated by the Africa Renewable Energy Initiative (AREI) is hinged on the fact that it improves access to electricity for households and for driving the productive sectors such as the agricultural sector, industrial, transportation, and the micro-, small and medium-scale enterprises. To achieve the expected energy demand in the continent and to reduce losses by about $10 \%$, an investment scale-up in Africa's electricity sector that primarily focuses on generation and distribution is essential (International Energy Agency 2019).

There exist only a few studies that have examined the factors that are responsible for the development of renewable energy in Africa and Sub-Saharan Africa (Emodi and Boo 2015; Giovannetti and Ticci 2016; Aliyu et al. 2018; da Silva et al. 2018; Salahuddin et al. 2020; Sharif et al. 2020). Specifically, da Silva et al (2018) examined the determinants of renewable energy in SubSaharan Africa over the experimental period of 1990-2014. In doing so, the impact of economic development vis-à-vis the real Gross Domestic Product per capita, energy usage, and population growth on renewable energy development has been examined. The study found that both economic development and energy usage contributed to the development of renewable energy during the experimental period while population growth appeared to have restricted the renewable energy development. Similarly, many studies have corroborated that economic growth which translates as income exhibits a significant and positive relationship with renewable energy development (Apergis and Payne 2010; Bilgili and Ozturk 2015; Bhattacharya et al. 2016; Alola and Alola 2018). However, Aguirre and Ibikunle (2014) and Pfeiffer and Mulder (2013), respectively, found that energy use and electricity consumption is negatively linked with renewable energy consumption.

While examining the potential of renewable energy electricity through policy applicability, Carley (2009) opined the important of the population growth rate in the assessment of the electric power capacity in the case of the United States of America. In the investigation, Carley (2009) employed the renewable portfolio standard (RPS) and examined the linkage of RPS policy implementation and the percentage of renewable energy generation across all the states. In view of the agricultural-related endowment in Africa, Rupf et al. (2016) examined the potential of biogas in Sub-Saharan Africa. The study revealed that the sources of biogas in the region include the organic fraction of municipal solid waste (OFMSW), domestic sewage, crop residues, livestock manure, and household feedstocks among others. Similarly, Giovannetti and Ticci (2016) employed the newly updated model of the Land Matrix to examine the relationship between investments in land and the development of biofuels in Sub-Saharan Africa. While the study employed agricultural land which is mainly used 
for cultivating biofuel crops such as cereals (considering the food-land-energy nexus hypothesis), it was observed that the factors of water resources, regulatory and security quality among others are essential and significant determinants of investment in land for biofuels.

Furthermore, Salim and Shafiei (2014) revealed that population and urbanization are both linked with renewable energy consumption and non-renewable energy consumption in the case of the Organization for Economic Corporation and Development (OECD) countries. The study found that the total population exerts a long-run positive and significant impact on both non-renewable and renewable energy consumption in the panel of the OECD countries. Although the result of the investigation further posited that the impact of the total population on renewable energy consumption is lower than that of the non-renewable energy consumption, the study found there to be a non-significant impact due to population density on renewable energy consumption. On the other hand, population density is observed to have resulted in a decline in non-renewable energy consumption in the panel countries. Importantly, the studies of Poumanyvong et al. (2012) and Salim and Shafiei (2014) found that the increased urbanization from road usage and transportation is responsible for a higher consumption of non-renewable energy especially in high income economies.

Although several studies in addition to the aforementioned have examined the determinant of energy forms or the causal link of energy sources with other variables (Ehrlich and Holdren 1971; Kraft and Kraft 1978; O'Neill et al. 2012; Shahbaz and Lean 2012), the current study potentially closes the existing gap by further incorporating agricultural added value and urbanization in the case of Sub-Saharan countries.

In light of the above motivation, the current study is designed to explore the potential determinants of renewable energy development in Africa. This is while considering the challenges that arise when meeting the lowcarbon energy gap in the continent through the adoption of climate actions (SDG-13) and responsible energy consumption (SDG-12) targets. To this end, the current study attempts to examine the effects of real Gross Domestic Product (RGDP), agricultural value-added (AG), urbanization (URB), and electricity consumption (ELE) on renewable energy consumption (REC) for selected SubSaharan African economies (including Benin, Botswana, Cameroon, Congo Republic, Cote d'ivoire, Ethiopia, Ghana, Kenya, Mauritius, Nigeria, South Africa, and Zimbabwe). Specifically, on the one hand, agricultural value added has been considered because of the importance of agriculture to the continent since the sector is considered to be the driver of growth and the provider of an enormous capacity for poverty and reduction inequality gap (United
Nations 2014). On the other hand, agriculture practices are believed to be a significant source of renewable energy source such as biofuels and at the same time, they contribute to environmental degradation either through land or chemical usage and other agricultural practices (Tubiello et al. 2015). Although the rate of urbanization is not uniform across all of the regions of Africa, increasing the rate of urbanization in West Africa, North Africa, and Southern Africa is significant. By incorporating the agricultural value added and urbanization in the energy model, the current study is poised to project a novel perspective and to close the gap found in the study by Adedoyin et al. (2020).

\section{Methodology}

\subsection{Data presentation}

By driving through with the objective of the current study, a handful of variables are employed. Importantly, renewable energy consumption is employed as the dependent variable against the independent variables, specifically the real Gross Domestic Product, agricultural value added, urbanization, and electricity consumption. In Table 1, other necessary information of the variable such as the unit of measurement and the source of the series are further presented.

Furthermore, the descriptive statistics of the series and the correlation between the variables are presented in Table 2. Giving the high standard deviation of the RGDP, the statistics of the variables implies that there is high heterogeneity in the economic development across the SubSaharan Africa region. A similar observation was found in the volume of electricity energy consumption in the region. Additionally, except for renewable energy consumption and urbanization, the series is observed to be positively skewed because of the positive tails exhibited by the series. Importantly, there is significant evidence of a correlation between all of the examined variables (see Table 2).

\subsection{Methodological procedures}

\subsubsection{Empirical model}

Following the studies of Asongu et al. (2020) and da Silva et al. (2018) among related others, the current study further presents a modified model that underpins the relationships between electricity energy consumption (ele) urbanization (urb), renewable energy consumption (rec), gross domestic product per capita (rgdp), and agriculture added value (ag) for the 12 selected African countries. In this case, the current model is uniquely presented as: 
Table 1 Indicators and unit of measurement. Source: Authors' computation
Table 2 Summary statistics and correlation analysis. Source: Authors' computation

\begin{tabular}{llll}
\hline Variables & Code & Unit of measurement & Source \\
\hline Real gross domestic product & RGDP & (Constant 2010 \$ USD) & WDI \\
Agricultural value added & AG & (Constant 2010 \$ USD) & WDI \\
Urbanization & URB & $(\%$ of total $)$ & WDI \\
Renewable energy & REC & $(\%$ of total final energy $)$ & WDI \\
Electricity consumption & ELE & $(\mathrm{KW} / \mathrm{h})$ & WDI \\
\hline
\end{tabular}

World Development Indicator 2020 database (https://data.worldbank.org/)

\begin{tabular}{llllll}
\hline & REC & RGDP & AG & URB & ELE \\
\hline Mean & 59.383 & 2375.369 & 19.478 & 41.378 & 751.999 \\
Median & 68.470 & 1292.750 & 20.489 & 42.503 & 188.856 \\
Maximum & 94.333 & 9163.633 & 63.831 & 66.368 & 4777.059 \\
Minimum & 5.352 & 163.623 & 1.828 & 12.621 & 21.627 \\
Std. Dev & 26.107 & 2220.732 & 13.595 & 13.593 & 1205.926 \\
Skewness & -0.713 & 1.249 & 0.575 & -0.372 & 2.291 \\
Kurtosis & 2.094 & 3.275 & 2.805 & 2.471 & 7.215 \\
Observations & 300 & 300 & 300 & 300 & 300 \\
Correlation coefficient & analysis & & & & \\
REC & 1 & & & & \\
GDP & $-0.701^{*}$ & 1.000 & $0.748^{*}$ & 1.000 & \\
AG & $0.392^{*}$ & $0.595^{*}$ & $-0.722^{*}$ & 1.000 & \\
URB & $-0.257^{*}$ & $0.798^{*}$ & $0.567^{*}$ & $0.453^{*}$ & \\
ELE & $-0.658^{*}$ & & & & \\
\hline
\end{tabular}

* represent $p<0.01$

$\operatorname{rec}_{i, t}=f\left(\operatorname{rgdp}_{i, t}, \operatorname{urb}_{i, t}, \operatorname{ele}_{i, t} \operatorname{ag}_{i, t} e_{i, t}\right)$

Therefore, the transformation of the above expression (Eq. 1) is transformed into a natural logarithmic algorithm:

$$
\begin{aligned}
\operatorname{lrec}_{i, t}=\alpha & +\beta_{1} \ln \operatorname{rgdp}_{i, t}+\beta_{2} \ln \operatorname{urb}_{i, t}+\beta_{3} \ln \mathrm{ele}_{i, t} \\
& +\beta_{4} \ln \operatorname{ag}_{i, t}+\varepsilon_{i, t}
\end{aligned}
$$

given that $t=1990, \ldots 2014, i=1,2,3, \ldots, 12$ and $\varepsilon$ is the error term such that cis iiid $\sim N\left(\mu, \sigma^{2}\right)$. Also, $\alpha$ and $\beta s$ are the slope and the response rate of the logarithms of the explanatory variables for each $i$ and $t$.

\subsubsection{The ARDL-pooled mean group (PMG) test}

The empirical route of the present study follows four pathways. First, the basic summary statistics and simple correlation analysis that have outlined the measures of central tendencies and measures of dispersion are reported in Table 2. Secondly, the investigation of the stationarity properties of the series was used to ameliorate the spurious analysis. To investigate the long-run equilibrium relationship, Kao's cointegration in conjunction with Pedroni techniques were employed. Third, the long-run and short- run analysis was examined by the Pool Mean Group Auto Regressive Distributed lag Model methodology simultaneously as advanced by Pesaran et al (1999). As such, the ARDL-PMG estimation employs the cointegration form of the ordinary ARDL model such that Eq. (2) was further estimated through the following expression:

$y_{i, t}=\phi_{i} \mathrm{EC}_{i, t}+\sum_{j=0}^{q-1} \beta_{i, t} \Delta X_{i, t-j}+\sum_{j=1}^{p-1} \lambda_{i, j} \Delta y_{i, t-j}+\varepsilon_{i, t}$

Given that $\mathrm{EC}_{i, t}=y_{i, t-1}-X_{i, t} \theta$ represents the error correction, $\phi$ is the coefficients of the speed of adjustment and $\theta$ is the long-run coefficients such that $X$ is the vector of the independent variables in the models, i.e., $X=f(\operatorname{lgdp}$, lele, lurb, lag).

Further information such as the hypothesis testing of the estimation approach has been omitted here because of space constraints. They are detailed in Pesaran et al. (1999). Moreover, to detect the causality direction among the investigated variables, the current study has explored the work of Dumitrescu and Hurlin (2012). 


\section{Results and discussion}

The current study set out to underpin the determinants of renewable energy consumption in Sub-Saharan African economies, a continent with rich energy dynamics. To achieve this hypothesized claim, a multivariate model was fitted. The first point of call in econometrics modeling is the eyeball testing of the preliminary analysis on how the data fares as in the investigation of the basic summary statistics and correlation analysis as highlighted in Table 2. Subsequently, the stationarity properties of the variables under review were conducted using the Levin et al. (2002), Im et al. (2003), and Fisher-ADF by Maddala and Wu (1999) panel unit root tests as documented in Table 3. The consensus of the entire test is found in the harmony of the mixed order of the integrated outlined variables. The stationarity test is pertinent to avoid the pitfalls of erroneous modeling and analysis. Subsequently, investigating the long-run properties of the series shows there to be a longrun equilibrium relationship between all of the considered variables as rendered in Table 4 using the Pedroni and Kao methodology.

The next step was to examine the magnitude of the long and sort run relationships between the variables. In Table 5, the equilibrium relationship has been validated by the Error Correction Term (ECT) showing the speed of adjustment of the variables. The ECT shows the equilibrium exit that the system equalizes by $34.8 \%$. This is statistically significant at $(p<0.01)$ on an annual basis due to the contributions of electricity consumption, urbanization, economic growth and agricultural value added. Economic growth in SSA increases the consumption of renewable energy in the short run by $0.128 \%$ while in the long run, a $1 \%$ increase in economic growth dampens the intake of renewable energy consumption by $0.402 \%$ at a $(p<0.01)$ statistically significant level. The current result resonates with the findings of Shah et al (2020) for D-8 countries. This implies that there is still room for more improvement in renewable energy in Africa. The region is mainly driven by the primary sector that is comprised of agricultural activities, mining and crude oil exploration.

Furthermore, agriculture has an inverse relationship with the dependent variable while in the long-run, agriculture is positive and elastic. There is a $1 \%$ increase in agricultural activities alongside the long-run increase renewable energy by $0.252 \%$. This is quite negligible given how the region is on the trajectory of disentangling its economic growth from pollutant emissions. The results also show that an increase in electricity consumption (from fossil sources) dampens the share of renewable energy utilization in the region. Interestingly, while Olanrewaju et al. (2019) found that oil rents and coal energy sources hamper renewable energy use according to a panel of five most populous and biggest economies in Africa, the study by Akintande et al. (2020) revealed that energy utilization and electricity power demand an increase in renewable energy consumption in the African region. The moderating role of urbanization was also explored as the long-run analysis shows that a high urban population increases the SSA energy consumption by a precise $1 \%$ increase in urbanization. This increases the renewable energy consumption by $0.881 \%$. This suggests that the region's urban population is

Table 3 Panel unit root tests

\begin{tabular}{|c|c|c|c|c|c|c|}
\hline \multirow[t]{2}{*}{ Variables } & \multicolumn{2}{|l|}{ LLC } & \multicolumn{2}{|l|}{ IPS } & \multicolumn{2}{|c|}{ Fisher-ADF } \\
\hline & Constant & Trend & Constant & Trend & Constant & Trend \\
\hline lnrec & -0.145 & 0.873 & 1.419 & -0.713 & 15.092 & 16.842 \\
\hline lnrgdp & $-4.849 *$ & $-18.129 *$ & $-7.887 *$ & $-13.141^{*}$ & $39.754 *$ & $277.511^{*}$ \\
\hline lnag & $-1.311^{* *}$ & $-2.184 * *$ & 0.019 & $-2.654 *$ & $25.462 *$ & $41.9811^{*}$ \\
\hline lnurb & -1.131 & $-6.325^{*}$ & 1.778 & $-8.444^{*}$ & $38.223 *$ & $137.511^{*}$ \\
\hline lnele & $-1.541 * * *$ & -0.886 & 2.827 & 2.485 & 16.948 & 11.534 \\
\hline$\Delta \operatorname{lnrec}$ & $-6.977 *$ & $-5.725^{*}$ & $-6.866^{*}$ & $-5.081^{*}$ & $91.837 *$ & $67.822 *$ \\
\hline$\Delta \ln r g d p$ & $-132.063^{*}$ & $27.743 *$ & $-47.033 *$ & $-7.837^{*}$ & $130.769 *$ & $107.801 *$ \\
\hline$\Delta \operatorname{lnag}$ & $-11.305^{*}$ & $-9.332 *$ & $-13.067 *$ & $-11.863^{*}$ & $192.175 *$ & $160.928 *$ \\
\hline$\Delta \operatorname{lnurb}$ & $-2.064 * *$ & -0.594 & -1.272 & 0.512 & 33.806 & 21.784 \\
\hline$\Delta$ lnele & $-7.356^{*}$ & $-7.181 *$ & $-6.955^{*}$ & $-6.590 *$ & $94.707 *$ & $85.906 *$ \\
\hline
\end{tabular}

$*, * *$ and $* * *$ represents are statistical significance rejection level at $1 \%, 5 \%$ and $10 \%$, respectively. $\Delta$ indicates first difference. Lag selection by SIC of maximum of 4 in all estimations. Here, LLC, IPS and Fisher-ADF means the Levin et al. (2002), Im et al. (2003), Fisher-ADF by Maddala and Wu (1999) panel unit root tests. Automatic lag selection is adopted for the estimations. Also, the rgdp, rec, ele, urb and ag respectively the, gross domestic product per capita, renewable energy consumption as percentage of final total energy consumption, urbanization and agricultural value added. Also, ln denotes natural logarithmic form of the considered variable 
Table 4 Pedroni and Kao cointegration results. Source: Authors computation

\begin{tabular}{|c|c|c|c|c|c|}
\hline & Statistic & Prob & W. Statistic & & Prob \\
\hline \multicolumn{6}{|c|}{ Alternative hypothesis: common AR coefficients (within-dimension) } \\
\hline Panel v-statistic & 2.256 & $0.012 * *$ & -1.340 & & 0.909 \\
\hline Panel rho-statistic & 1.873 & 0.970 & 1.602 & & 0.946 \\
\hline Panel PP-statistic & -0.830 & 0.203 & -2.562 & & $0.005^{*}$ \\
\hline \multirow[t]{2}{*}{ Panel ADF-statistic } & -2.280 & $0.011 * *$ & -2.855 & & $0.002 *$ \\
\hline & \multicolumn{3}{|c|}{ Statistic } & Prob & \\
\hline \multicolumn{6}{|c|}{ Alternative hypothesis: individual AR coefficient (between-dimension) } \\
\hline Group rho-statistic & & 2.571 & & 0.995 & \\
\hline Group PP-statistic & & -2.353 & & $0.009 * *$ & \\
\hline \multirow[t]{2}{*}{ Group ADF-statistic } & & -1.657 & & $0.049 * *$ & \\
\hline & \multicolumn{3}{|c|}{$t$-Stat } & & Prob \\
\hline \multicolumn{6}{|l|}{ Kao cointegration test } \\
\hline \multicolumn{2}{|l|}{$\mathrm{ADF}$} & \multicolumn{2}{|l|}{$-2.456^{*}$} & & \multirow[t]{3}{*}{0.007} \\
\hline Residual variance & \multicolumn{3}{|c|}{10.545} & & \\
\hline HAC variance & \multicolumn{3}{|c|}{14.670} & & \\
\hline
\end{tabular}

Note the Superscript $* * *, * *$ and $*$ means statistical rejection level statistics at $1 \%, 5 \%$ and $10 \%$ significance level, respectively

Table 5 Result of PMG-ARDL (2, 1, 1, 1, 1). Source: Authors computation

\begin{tabular}{|c|c|c|c|c|}
\hline \multicolumn{5}{|c|}{ Model: LNREC $=F($ LNRGDP, LNAG, LNURB, LNELE $)$} \\
\hline Variable & Coefficient & Std. Error & $T$-stat & $p$ value \\
\hline \multicolumn{5}{|l|}{ Long run } \\
\hline lngdp & $-0.402 *$ & 0.051 & -7.865 & 0.000 \\
\hline $\operatorname{lnag}$ & $0.252 *$ & 0.037 & 6.776 & 0.000 \\
\hline lnele & $-0.752 *$ & 0.040 & -14.347 & 0.000 \\
\hline lnurb & $0.881^{*}$ & 0.102 & 8.661 & 0.000 \\
\hline \multicolumn{5}{|l|}{ Short run } \\
\hline $\operatorname{ECT}(-1)$ & $-0.348^{* * *}$ & 0.113 & -3.063 & 0.003 \\
\hline$\Delta \operatorname{lng} \mathrm{dp}$ & 0.128 & 0.163 & 0.787 & 0.432 \\
\hline$\Delta \operatorname{lnag}$ & -0.066 & 0.059 & -1.131 & 0.259 \\
\hline$\Delta$ lnele & 0.104 & 0.263 & 0.398 & 0.691 \\
\hline$\Delta \operatorname{lnurb}$ & $-33.600 * * *$ & 19.339 & -1.737 & 0.084 \\
\hline Constant & $2.461^{*}$ & 0.852 & 2.887 & 0.004 \\
\hline
\end{tabular}

Note the Superscript $* * *, * *$ and $*$ denotes statistical rejection at $1 \%$, $5 \%$ and $10 \%$, respectively

conscious of the environment and the implications of a pollutant driven economy. However, a related study for the case of Africa by da Silva et al. (2018) offers evidence that such a population impedes renewable energy development.

Table 6 presents the analysis of the causality test. The causality test shows the predictability of the outlined variables among each other over the sample period. SSA is characterized by its primary and large-scale agrarian activities. This is seen in the two-way causality between
Table 6 Results of the (Dumitrescu and Hurlin 2012) panel causality. Source: Authors computation

\begin{tabular}{|c|c|c|c|}
\hline Null hypothesis: & W-Stat & Zbar-Stat & Prob \\
\hline GDPC $\neq>$ REC & $5.10647 * * *$ & 3.87852 & 0.0001 \\
\hline $\mathrm{REC} \neq>\mathrm{GDPC}$ & 3.22747 & 1.32721 & 0.1844 \\
\hline $\mathrm{AG} \neq>\mathrm{REC}$ & $4.25051 * * *$ & 2.71629 & 0.0066 \\
\hline $\mathrm{REC} \neq>\mathrm{AG}$ & $3.62146^{*}$ & 1.86217 & 0.0626 \\
\hline $\mathrm{URB} \neq>\mathrm{REC}$ & $4.45936 * * *$ & 2.99987 & 0.0027 \\
\hline $\mathrm{REC} \neq>\mathrm{URB}$ & $7.70902 * * *$ & 7.41226 & 0.0000 \\
\hline $\mathrm{ELE} \neq>\mathrm{REC}$ & $5.78393 * * *$ & 4.79838 & 0.0000 \\
\hline $\mathrm{REC} \neq>\mathrm{ELE}$ & 2.54662 & 0.40275 & 0.6871 \\
\hline $\mathrm{AG} \neq>\mathrm{GDPC}$ & $7.91002 * * *$ & 7.68517 & 0.0000 \\
\hline $\mathrm{GDPC} \neq>\mathrm{AG}$ & $4.35067 * * *$ & 2.85229 & 0.0043 \\
\hline $\mathrm{URB} \neq>\mathrm{GDPC}$ & $7.86695 * * *$ & 7.62669 & 0.0000 \\
\hline GDPC $\neq>$ URB & $4.51419 * * *$ & 3.07432 & 0.0021 \\
\hline $\mathrm{ELE} \neq>$ GDPC & 2.38372 & 0.18157 & 0.8559 \\
\hline $\mathrm{GDPC} \neq>\mathrm{ELE}$ & $5.10778 * * *$ & 3.88030 & 0.0001 \\
\hline $\mathrm{URB} \neq>\mathrm{AG}$ & $6.03840 * * *$ & 5.14388 & 0.0000 \\
\hline $\mathrm{AG} \neq>\mathrm{URB}$ & $7.98391 * * *$ & 7.78550 & 0.0000 \\
\hline $\mathrm{ELE} \neq>\mathrm{AG}$ & 2.79242 & 0.73650 & 0.4614 \\
\hline $\mathrm{AG} \neq>\mathrm{ELE}$ & 3.20677 & 1.29911 & 0.1939 \\
\hline ELE $\neq>$ URB & 2.94137 & 0.93874 & 0.3479 \\
\hline $\mathrm{URB} \neq>$ ELE & $5.57357 * * *$ & 4.51274 & 0.0000 \\
\hline
\end{tabular}

$*$, ** and *** represents $0.01,0.05$ and 0.10 rejection statistical level, respectively

agriculture and economic growth. This refers to agriculture driven by economic growth and vice versa. This finding is 
consistent with the findings of Agboola and Bekun (2019). On the contrary, in BRICS as the study by Balsalobre et al. (2019) show, agriculture is seen to promote pollutant emissions. This indicates that agriculture is a good predictor of economic growth. Furthermore, feedback causality is seen to result from urbanization and electricity consumption, i.e both variables Granger causes each other. This implies that high urban growth compels a higher level of electricity consumption. Urbanization and renewable energy consumption have a bi-directional causality flow. However, the increase in the region's electricity consumption is from non-renewable energy. Additionally, between agriculture and renewable energy consumption is a feedback relationship while a unidirectional causality can be seen between economic growth and renewable energy consumption. These causality analyses reveal the nature of the causality between economic growth and other macroeconomic indicators like urbanization, agricultural value added, electricity consumption, and renewable energy consumption. For instance, the causality seen between economic growth and renewable energy is aligned with the paradigm where the economy is driven by clean energy.

However, this fit requires more actions on the part of both the government administrators and private partnerships. The need for a green economy is being pursued by all continents and Africa is not left out of this, leading to several action plans such as the National Renewable Energy Action Plan (NREAP) and the Renewable Energy Policy (EREP). The ECOWAS Energy Efficiency Policy (EEEP) was also inaugurated in ECOWAS. All of the highlighted programs are in line with the mitigation of climate change action (SDG-13) from fossil-fuel concentration in the energy mix to the promotion of responsible consumption (SDG-12). However, this fit requires more action on the part of both government administrators and private partnership in terms of the commitment to local and international environmental treaties that foster energy efficiency, security, and sustainability at large.

From a policy perspective, given the highlighted revelations, the following counsel were rendered to all stakeholders and energy users and practitioners. (i) First, the SSA region needs to sustain its momentum to further increase the share of renewable energy consumption from the total fossil energy sources. (ii) Second, for the region to achieve fit when it comes to attaining energy efficiency, there is a need for more pragmatic actions to reinforce the commitments. This pragmatic actions of the SSA's commitment include the national and regional regulatory treaties. Considering that the sustainable development goals (SDGs) incorporate 17 distinct objectives such as tourism, health, and other sector-related concepts, the SSA could further implement energy efficiency policies in every sector of the region's economy. In line with the implementation of this inclusive policy, the achievement of Vision 2030 by the SSA is almost inevitable.

\section{Conclusion}

Most economies around the globe are on the edge and working assiduously to achieve their environmental sustainability targets. Sub-Saharan Africa (SSA) is no exception to this phenomenon. This has led most government administrators to disentangle their economic growth trajectory from pollutant emissions. To underpin this objective, the current study explored the theme for selected countries in SSA. The region is known to be more of a primary industry well driven by agriculture, mining, and crude oil exploration and exploitation. The recent study incorporates agriculture, urbanization, and the energy from fossil fuel sources as the determinant of renewable energy in Sub-Saharan African economies.

The empirical findings from this study indicate the longrun equilibrium relationship between electricity consumption, urbanization, agriculture, renewable energy consumption, and economic growth as reported by Pedroni and Kao's cointegration test over the investigated time span. The long-run regression from the ARDL-PMG shows there to be a statistically inverse significant relationship between economic growth and renewable energy consumption. This pattern is seen in the electricity consumption. These outcomes imply that an increased share of non-renewable energy consumption (dirty energy consumption) dampens the share of renewable energy consumption. This implies that there is need for paradigm shift to cleaner energy technologies. This position is supported by Schwerhoff and Sy (2017) who asserted that the higher consumption of renewable energy will facilitate the attainment of the seven SDG of clean and efficient energy access by 2030. This in turn translates to better welfare for the populace in SSA and other regions. Additionally, the increased urban population is triggering a higher consumption of energy to drive industries like agriculture where there is machinery like tractors and combine harvesters, among other tools. This is supported by the causality analysis where a feedback causality relationship is observed between urbanization and renewable energy consumption, as well as agriculture and economic growth. This means that the urban population in Sub-Saharan African economies is conscious of clean energy. 
Acknowledgements Authors appreciate the Editorial office of the Journal and the anonymous referees for providing relevant comments.

Authors contribution AAA: Writing-original draft, Formal analysis. Conceptualization, Formal analysis, Investigation, Methodology. FVB: Writing — original draft and Data curation.

Funding Open Access funding provided by University of Vaasa (UVA). None.

\section{Declaration}

Conflict of interest Authors declare that there is no known competing financial interests or personal relationship that could have influenced the study.

Open Access This article is licensed under a Creative Commons Attribution 4.0 International License, which permits use, sharing, adaptation, distribution and reproduction in any medium or format, as long as you give appropriate credit to the original author(s) and the source, provide a link to the Creative Commons licence, and indicate if changes were made. The images or other third party material in this article are included in the article's Creative Commons licence, unless indicated otherwise in a credit line to the material. If material is not included in the article's Creative Commons licence and your intended use is not permitted by statutory regulation or exceeds the permitted use, you will need to obtain permission directly from the copyright holder. To view a copy of this licence, visit http://creativecommons. org/licenses/by/4.0/.

\section{References}

Adedoyin FF, Alola AA, Bekun FV (2020) The nexus of environmental sustainability and agro-economic performance of SubSaharan African countries. Heliyon 6(9):e04878. https://doi.org/ 10.1016/j.heliyon.2020.e04878

Africa Renewable Energy Initiative (2019) https://www.2030spot light.org/en/book/605/chapter/ii71-africa-renewable-energyinitiative. (Accessed 31st April 2020)

Agboola MO, Bekun FV (2019) Does agricultural value added induce environmental degradation? Empirical evidence from an agrarian country. Environ Sci Pollut Res 26(27):27660-27676. https:// doi.org/10.1007/s11356-019-05943-z

Aguirre M, Ibikunle G (2014) Determinants of renewable energy growth: a global sample analysis. Energy Policy 69:374-384. https://doi.org/10.1016/j.enpol.2014.02.036

Akintande OJ, Olubusoye OE, Adenikinju AF, Olanrewaju BT (2020) Modeling the determinants of renewable energy consumption: evidence from the five most populous nations in Africa. Energy 206:117992. https://doi.org/10.1016/j.energy.2020.117992

Aliyu AK, Modu B, Tan CW (2018) A review of renewable energy development in Africa: a focus in South Africa, Egypt and Nigeria. Renew Sustain Energy Rev 81:2502-2518. https://doi. org/10.1016/j.rser.2017.06.055

Alola AA, Alola UV (2018) Agricultural land usage and tourism impact on renewable energy consumption among Coastline Mediterranean Countries. Energy Environ 29(8):1438-1454. https://doi.org/10.1177/0958305X18779577

Alola AA, Saint Akadiri S (2021) Clean energy development in the United States amidst augmented socioeconomic aspects and country-specific policies. Renew Energy 169:221-230. https:// doi.org/10.1016/j.renene.2021.01.022
Apergis N, Payne JE (2010) Coal consumption and economic growth: evidence from a panel of OECD countries. Energy Policy 38(3):1353-1359. https://doi.org/10.1016/j.enpol.2009.11.016

Asongu SA, Agboola MO, Alola AA, Bekun FV (2020) The criticality of growth, urbanization, electricity and fossil fuel consumption to environment sustainability in Africa. Sci Total Environ 712:136376. https://doi.org/10.1016/j.scitotenv.2019. 136376

Balsalobre-Lorente D, Driha OM, Bekun FV, Osundina OA (2019) Do agricultural activities induce carbon emissions? The BRICS experience. Environ Sci Pollut Res 26(24):25218-25234. https:// doi.org/10.1007/s11356-019-05737-3

Bhattacharya M, Paramati SR, Ozturk I, Bhattacharya S (2016) The effect of renewable energy consumption on economic growth: evidence from top 38 countries. Appl Energy 162:733-741. https://doi.org/10.1016/j.apenergy.2015.10.104

Bilgili F, Ozturk I (2015) Biomass energy and economic growth nexus in G7 countries: evidence from dynamic panel data. Renew Sustain Energy Rev 49:132-138. https://doi.org/10.1016/ j.rser.2015.04.098

Carley S (2009) State renewable energy electricity policies: an empirical evaluation of effectiveness. Energy Policy 37(8):3071-3081. https://doi.org/10.1016/j.enpol.2009.03.062

da Silva PP, Cerqueira PA, Ogbe W (2018) Determinants of renewable energy growth in Sub-Saharan Africa: evidence from panel ARDL. Energy 156:45-54. https://doi.org/10.1016/j. energy.2018.05.068

Dumitrescu EI, Hurlin C (2012) Testing for Granger non-causality in heterogeneous panels. Econ Model 29(4):1450-1460. https://doi. org/10.1016/j.econmod.2012.02.014

Ehrlich PR, Holdren JP (1971) Impact of population growth. Science 171(3977):1212-1217

Emodi NV, Boo KJ (2015) Sustainable energy development in Nigeria: current status and policy options. Renew Sustain Energy Rev 51:356-381. https://doi.org/10.1016/j.rser.2015.06.016

Giovannetti G, Ticci E (2016) Determinants of biofuel-oriented land acquisitions in Sub-Saharan Africa. Renew Sustain Energy Rev 54:678-687. https://doi.org/10.1016/j.rser.2015.10.008

Im KS, Pesaran MH, Shin Y (2003) Testing for unit roots in heterogeneous panels. J Econom 115:53-74. https://doi.org/10. 1016/S0304-4076(03)00092-7

International Energy Agency (2019) Africa energy outlook 2019. https://www.iea.org/reports/africa-energy-outlook-2019\#renew ables. (Accessed 30 March 2020)

International Renewable Energy Agency (2019) Africa's renewable future. the path to sustainable growth. https://irena.org/publica tions/2013/Jan/Africas-Renewable-Future-the-Path-to-Sustain able-Growth. (Accessed 30 March 2020)

Kraft J, Kraft A (1978) On the relationship between energy and GNP. J Energy Dev 3:401-403

Levin A, Lin CF, Chu CSJ (2002) Unit root tests in panel data: asymptotic and finite-sample properties. J Econom 108(1):1-24. https://doi.org/10.1016/S0304-4076(01)00098-7

Maddala GS, Wu S (1999) A comparative study of unit root tests with panel data and a new simple test. Oxf Bull Econ Stat 61(S1):631-652. https://doi.org/10.1111/1468-0084.0610s1631

National Aeronautics and Space Administration (2020) https:// climate.nasa.gov/causes/. (Accessed 27 March 2020)

National Geographic (2019) Renewable energy, explained. https:// www.nationalgeographic.com/environment/energy/reference/ renewable-energy/. (Accessed 27 March 2020)

Olanrewaju BT, Olubusoye OE, Adenikinju A, Akintande OJ (2019) A panel data analysis of renewable energy consumption in Africa. Renew Energy 140:668-679. https://doi.org/10.1016/j. renene.2019.02.061 
O'Neill BC, Ren X, Jiang L, Dalton M (2012) The effect of urbanization on energy use in India and China in the iPETS model. Energy Econ 34:S339-S345. https://doi.org/10.1016/j. eneco.2012.04.004

Ozturk M, Dincer I (2020) Development of renewable energy system integrated with hydrogen and natural gas subsystems for cleaner combustion. J Nat Gas Sci Eng 83:103583. https://doi.org/10. 1016/j.jngse.2020.103583

Pesaran MH, Shin Y, Smith RP (1999) Pooled mean group estimation of dynamic heterogeneous panels. J Am Stat Assoc 94(446):621-634. https://doi.org/10.1080/01621459.1999. 10474156

Pfeiffer B, Mulder P (2013) Explaining the diffusion of renewable energy technology in developing countries. Energy Econ 40:285-296. https://doi.org/10.1016/j.eneco.2013.07.005

Poumanyvong P, Kaneko S, Dhakal S (2012) Impacts of urbanization on national transport and road energy use: evidence from low, middle- and high-income countries. Energy Policy 46:268-277. https://doi.org/10.1016/j.enpol.2012.03.059

Rafiq S, Bloch H, Salim R (2014) Determinants of renewable energy adoption in China and India: a comparative analysis. Appl Econ 46(22):2700-2710. https://doi.org/10.1080/00036846.2014. 909577

Rupf GV, Bahri PA, de Boer K, McHenry MP (2016) Broadening the potential of biogas in Sub-Saharan Africa: an assessment of feasible technologies and feedstocks. Renew Sustain Energy Rev 61:556-571. https://doi.org/10.1016/j.rser.2016.04.023

Salahuddin M, Habib MA, Al-Mulali U, Ozturk I, Marshall M, Ali MI (2020) Renewable energy and environmental quality: a secondgeneration panel evidence from the Sub Saharan Africa (SSA) countries. Environ Res 191:110094. https://doi.org/10.1016/j. envres.2020.110094

Salim RA, Shafiei S (2014) Urbanization and renewable and nonrenewable energy consumption in OECD countries: an empirical analysis. Econ Model 38:581-591. https://doi.org/10.1016/j. econmod.2014.02.008

Schwerhoff G, Sy M (2017) Financing renewable energy in AfricaKey challenge of the sustainable development goals. Renew Sustain Energy Rev 75:393-401. https://doi.org/10.1016/j.rser. 2016.11.004

Shah SZ, Chughtai S, Simonetti B (2020) Renewable energy, institutional stability, environment and economic growth nexus of D-8 countries. Energ Strat Rev 29:100484. https://doi.org/10. 1016/j.esr.2020.100484

Shahbaz M, Lean HH (2012) Does financial development increase energy consumption? The role of industrialization and urbanization in Tunisia. Energy Policy 40:473-479. https://doi.org/10. 1016/j.enpol.2011.10.050

Sharif A, Baris-Tuzemen O, Uzuner G, Ozturk I, Sinha A (2020) Revisiting the role of renewable and non-renewable energy consumption on Turkey's ecological footprint: evidence from Quantile ARDL approach. Sustain Cities Soc 57:102138. https:// doi.org/10.1016/j.scs.2020.102138

Tubiello FN, Salvatore M, Ferrara AF, House J, Federici S, Rossi S, Prosperi P (2015) The contribution of agriculture, forestry and other land use activities to global warming, 1990-2012. Glob Change Biol 21(7):2655-2660. https://doi.org/10.1111/gcb. 12865

Tugcu CT, Menegaki AN, Ozturk I (2020) Renewable vs nonrenewable energy consumption as a driver of government deficit in net energy importing countries. Asian Econ Financ Rev 10(10):1100-1114. https://doi.org/10.18488/journal.aefr.2020. 1010.1100 .1114

United Nations (2014) Agriculture in Africa. Transformation and outlook. https://www.un.org/africarenewal/topic/agriculture. (Accessed 31st March 2020) 